\title{
Induction of luteal activity and progesterone secretion in the nonpregnant one-humped camel (Camelus dromedarius)*
}

\author{
M. Marie and A. Anouassi \\ Department of Reproduction and A.I., Hassan II Institute of Agronomy and Veterinary Medicine, \\ B.P. 6202 Rabat-Instituts, Morocco
}

\begin{abstract}
Summary. Corpora lutea $(n=20)$ were detected in 5 one-humped female camels studied during a period of 4 months. Complete mating by a vasectomized male, male introduction into the pen of females without mating, or a progesterone decrease from a previous corpus luteum were followed by a similar progesterone pattern. A maximal plasma concentration of $4.5 \pm 1.5 \mathrm{ng}$ progesterone $/ \mathrm{ml}(2.7-8.8 \mathrm{ng} / \mathrm{ml})$ occurred $8.55 \pm 1.32$ days (6-11 days) after the inducing stimulus. Luteal regression, beginning $8.65 \pm 1.18$ days after the stimulus, was completed at Day $11.55 \pm 1.05$. Morphological development of ovarian structures, detected by rectal palpation, was in synchrony with the progesterone increase, but there was a prolonged period of regression. Females accepted mating up to 7 days after the ovulatory stimulus, when progesterone levels were as high as $3.5 \mathrm{ng} / \mathrm{ml}$. This study establishes the absence of pseudopregnancy in the one-humped female camel, and offers opportunities for improving the management of reproduction. It also shows that ovulatory stimuli other than mating can be effective in these animals.
\end{abstract}

\section{Introduction}

Evidence that the dromedary (Camelus dromedarius) is an induced ovulator is provided by the absence of corpus luteum formation when females are not mated (Nawito et al., 1968; Musa \& Abusineina, 1978; Elias et al., 1984), and by the release of LH after mating (Marie \& Anouassi, 1986). In induced ovulators, a non-fertile service or other ovulatory stimulus is followed by a non-fertile period related to the life-span of the corpora lutea induced.

For several of these species, luteal activity has been estimated by frequent blood sampling and progesterone evaluation. These observations indicate the existence of a pseudopregnancy, which can be as long as the pregnancy, as in the mink (Møller, 1973) and the ferret (Heap \& Hammond, 1974), or at least equal to half the duration of pregnancy. Pseudopregnancy lasts 15-18 days in the rabbit (Miller \& Keyes, 1976), 36-39 days (Wildt et al., 1981) or 40-50 days (Verhage et al., 1979) in the cat, and one observation made on a jaguar (Wildt et al., 1979) suggests a pattern similar to that of the cat.

On the other hand, data available for camelids, although less complete, indicate a shorter time-course for the corpora lutea in the non-pregnant females. On the basis of luteal or plasma progesterone concentrations obtained at discrete intervals, this duration has been estimated as 8-16 days in the llama (England et al., 1969), 8-13 days in the alpaca (Fernandez-Baca et al., 1970, 1979), and 10-15 days in the bactrian camel (Y. H. Gao, Y. S. Xu, H. Y. Wang, G. Q. Zeng, \&

\footnotetext{
*Reprint requests to Dr A. Anouassi.
} 
G. T. Jiang, personal communication). In the llama and the alpaca (Sumar \& Garcia, 1986), milk progesterone concentration is maximal at 3 days after copulation and returns to low levels by 10 or 11 days post coitum in the absence of fertilization.

The corpus luteum of the one-humped camel has been described morphologically and histologically (Tayeb, 1950; Shalash \& Nawito, 1964; Abdalla, 1965; Abdo et al., 1969; Nawar et al., 1978; Musa, 1979), but from material collected in slaughterhouses and generally from pregnant females. Progesterone secretion has been described (Assoue1, 1983; Elias et al., 1984), but only during pregnancy. Finally, the only information concerning the duration of luteal function in the absence of pregnancy has been collected by Musa \& Abusineina (1978) who observed, by rectal palpation, that corpora lutea disappeared from the ovary in about 1 week.

The purpose of this study was to determine the occurrence of luteal activity and the time-course of associated progesterone secretion in the dromedary after a sexual stimulus such as a complete mating, male presence, or excitation of the genital organs.

\section{Materials and Methods}

Animals. Five intact, nonpregnant females, 5-8 years old, and one vasectomized male, 8 years old, were used. Animais were fed with wheat straw (ad libitum) supplemented by lucerne hay and barley grain.

The experiment was conducted from late December to late April. Females were confined together in a large pen, apart from the male, out of sight and smell. They were introduced in the male's pen for 3-h periods, in the presence of the experimenter, and matings, if any, were noted. Experimental treatments were as follows. In Group A, to determine whether any luteal activity can occur in the absence of sexual stimulation other than vaginal or rectal manipulation, females were not presented to the male for 20-40-day periods, either from the end of December to the end of January, or during March. Seven of these sequences were performed. In Group B, to identify the ovulation-inducing mating stimulus, females were introduced in the male's pen daily until they mated, and each mated female was isolated for 2 weeks ( 9 sequences). In Group C, to determine duration of male acceptance after an ovulatory stimulus, females were presented to the male during 7-11 consecutive days, regardless of whether mating occurred, and then isolated for 10-20 days ( 9 sequences).

During the experimental period, females were subjected to vaginal stimulation with a vaginoscope and, from the end of January, to daily rectal palpation to evaluate the development of ovarian structures. A daily blood sample was obtained from the jugular vein in an evacuated collection tube containing sodium citrate; blood was immediately centrifuged, and plasma stored at $-20^{\circ} \mathrm{C}$ until progesterone assay was performed.

Rectal palpation. Females were restrained in a sitting position with ropes. The bifurcation of the uterine body is easily located; the right horn is short and rectilinear, laterally orientated, with the ovary at its extremity. The left horn is bigger and incurved backwards, which makes the palpation of the left ovary more difficult. The ovaries are situated at a distance of $40-50 \mathrm{~cm}$ from the vulvar commissure, confined in a mesenteric fold. Each ovary is flattened and $2-3 \mathrm{~cm}$ long $1 \cdot 5-2 \mathrm{~cm}$ wide and $0.5-1 \mathrm{~cm}$ thick.

Progesterone assay. Progesterone was measured by the radioimmunoassay method described for plasma by Marie et al. (1984), the only modification being the use of $2 \mathrm{ml}$ diethyl ether for extraction. Specificity of the antibody has been described by Beckers et al. (1975): cross-reaction was $7 \cdot 2 \%$ with pregnenolone, $5 \cdot 3 \%$ with $17 \alpha$-hydroxyprogesterone, $1.5 \%$ with $20 \beta$-dihydroprogesterone, and $0.8 \%$ with testosterone. Efficiency of extraction was $91.9 \pm 1.8 \%$. Assay sensitivity, estimated from the confidence interval of blanks, was $9.8 \mathrm{pg} / \mathrm{tube}(0.11 \mathrm{ng} / \mathrm{ml}$ plasma). Coefficients of variation for plasmas containing 0.43 and $2.97 \mathrm{ng}$ progesterone $/ \mathrm{ml}$ were respectively 4.3 and $3.5 \%$ for intra-assay variation, and $24 \cdot 3$ and $12.5 \%$ for inter-assay variation.

Assessment of progesterone patterns. Progesterone patterns were analysed with the mathematical model described by Yenikoe et al. (1981), which is a sequential combination of a logistic and an exponential function.

For the period between the ovulating stimulus $(t=0)$ and the start of the progesterone decrease $(t=\mathbf{T})$, the progesterone level $(\mathbf{P}(t))$ was fitted to a logistic function:

$$
\mathrm{P}(t)=\mathrm{a} /(1+\mathrm{b} \times \exp (-\mathrm{c} \times t))
$$

Parameters $\mathrm{a}, \mathrm{b}$ and $\mathrm{c}$ have been estimated by the Gauss-Marquardt least-squares method for non-linear models (Marquardt, 1963), using the UWLONG fortran program (Bachacou et al., 1981), on a Mini6 Bull-CII computer.

Values observed during the phase of decreasing progesterone were fitted to an exponential model:

$$
\mathbf{P}(t)=\mathbf{P}(\mathbf{T}) \times \exp (-\mathrm{d} \times(t-\mathrm{T}))
$$

To evaluate parameter $d$, adjustments have been made by linear regression after logarithmic transformation of progesterone values. 
Accuracy of adjustments was estimated by the values of the coefficients of determination. Differences between groups of observations for these variables were tested by one-way least-squares analysis of variance (Lebart et al., 1980). Data presented in the text are expressed by the means and standard deviations.

\section{Results}

\section{Induction of luteal activity}

When females were maintained for long periods (20-41 days) in the absence of contact with the male, corpora lutea were not induced: progesterone was always $<0.7 \mathrm{ng} / \mathrm{ml}(0.3 \pm 0.1 \mathrm{ng} / \mathrm{ml})$. Rectal palpations showed that the ovaries were not inactive, but contained structures with longterm development, which is a characteristic of follicular development: they reached a size of $35 \mathrm{~mm}$ in about 2 weeks, remained at the same size for 10-12 days, and regressed during the next 12-20 days, without rupture.

Of 15 matings of females with low levels $(<1 \mathrm{ng} / \mathrm{ml})$ of progesterone, $11(73 \%)$ were followed by a consistent elevation of plasma progesterone (Fig. 1), indicating the induction of luteal formation. The length of matings followed by an ovulation (5-15 min, 8.3 $\pm 3.4 \mathrm{~min}$ ) was not significantly different from the length of matings not followed by an ovulation (5-17 min, $10 \cdot 0 \pm 5 \cdot 1 \mathrm{~min}$ )

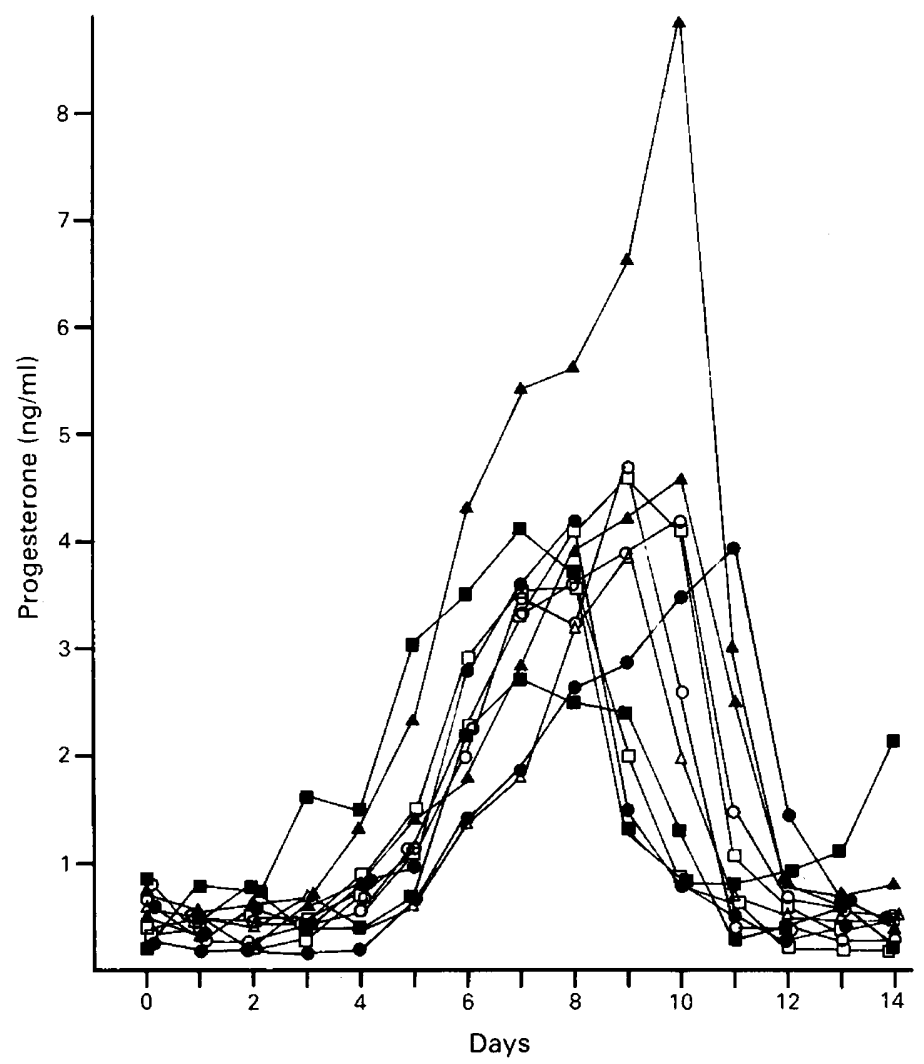

Fig. 1. Plasma progesterone concentrations after mating (Day 0) in the one-humped camel $(n=11)$. 


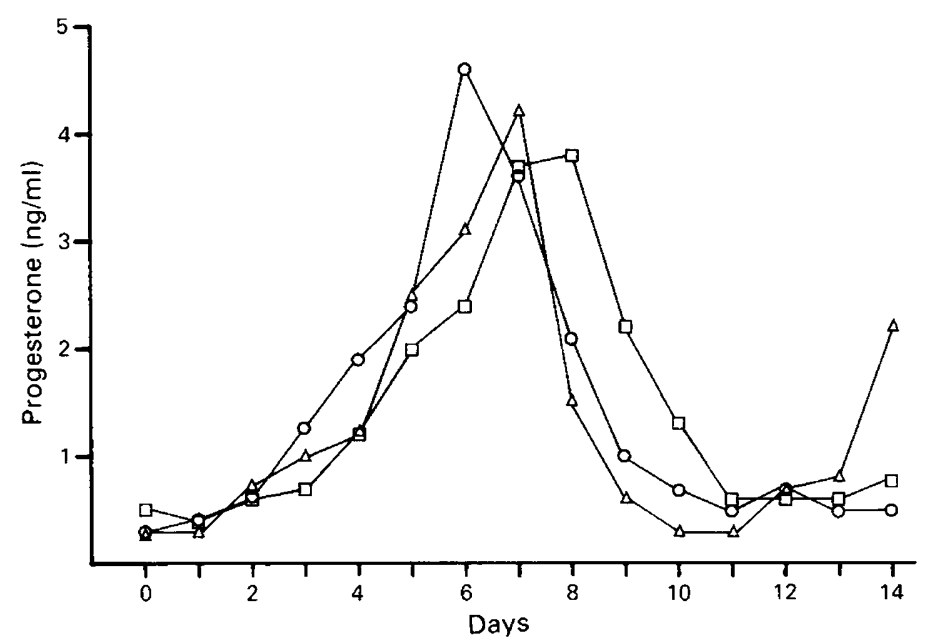

Fig. 2. Plasma progesterone concentrations after male introduction (Day 0 ) in the one-humped camel $(n=3)$.

In 4 instances, introduction of a male after a prolonged period of separation was not associated with a mating, but in 3 of these cases a progesterone pattern similar to that observed after a mating was detected (Fig. 2).

Elevation of progesterone concentrations was observed in another 2 animals, but it was not possible to associate these corpora lutea with an obvious inducing stimulus: the male was present on consecutive days during their formation, but no mating was observed, and they were not preceded by another corpus luteum. The data for these animals are not included in the figures.

In 5 of 16 cases in females not presented to the male, a second characteristic progesterone pattern was observed immediately after the decrease of progesterone secretion from the first corpus luteum (Fig. 3); no subsequent luteal activity was detected in these females. The hypothesis that withdrawal of progesterone may induce luteal activity in the one-humped camel was tested by insertion of a Silicone spiral impregnated with 2.25 g progesterone (PRID: Abbot Laboratories, Agricultural and Veterinary Products Division, Queenborough, Kent, U.K.) in the vagina of 4 females for a period of 6 days in the last week of April. Plasma progesterone was maintained at a relatively stable level $(5-8 \mathrm{ng} / \mathrm{ml})$ while the device was present, and fell rapidly after its removal. In 1 of the 4 females, a secretion of progesterone associated with luteal activity was observed. Therefore, the total incidence of corpora lutea (6) following a previous corpus luteum or exogenous progesterone ( 26 sequences) in the absence of stimulation by the male was $23 \%$.

\section{Progesterone secretion during luteal activity}

Mating-induced corpora lutea. Progesterone concentrations (Fig. 1) remained low during the first 4-5 days post coitum ( $<1 \mathrm{ng} / \mathrm{ml}$ in 9 of 11 observations at Day 4 , and in 4 at Day 5), then increased steadily to reach a maximum of $4.5 \pm 1.5 \mathrm{ng} / \mathrm{ml}(2.7-8.8 \mathrm{ng} / \mathrm{ml})$ between Days 7 and 11 post coitum ( $8.9 \pm 1.3$ days). An abrupt decrease of progesterone concentration was observed soon after this maximum, generally the following day, and values $<1 \mathrm{ng} / \mathrm{ml}$ were observed from 10 to 13 days p.c., the secretory activity being completed at Day 11 to 14 p.c. $(12 \cdot 0 \pm 1 \cdot 0$ days). Progesterone values therefore remained $>1 \mathrm{ng} / \mathrm{ml}$ for $5-8$ consecutive days $(6 \cdot 3 \pm 1 \cdot 1$ days).

Male-induced corpora lutea. The three patterns associated with corpora lutea induced by male introduction, without mating, are represented in Fig. 2. The maximal level, $4 \cdot 2 \pm 0.4 \mathrm{ng} / \mathrm{ml}$ 
(3.8-4.6 ng/ml), was observed at Days 6, 7 and 8 , which is not statistically different from the value observed after mating; the end of progesterone decrease was noted at Day 10 or 11 .

Progesterone-induced corpora lutea. The five patterns observed immediately after formation of a first corpus luteum and the one obtained after administration of exogenous progesterone are shown in Fig. 3. Progesterone remained $>1 \mathrm{ng} / \mathrm{ml}$ for 5-7 days $(6 \cdot 2 \pm 1 \cdot 0$ days), with maximal concentrations of $4.63 \pm 1.91 \mathrm{ng} / \mathrm{ml}(3.4-8.4 \mathrm{ng} / \mathrm{ml})$; these values did not differ statistically from those obtained in the two previous groups. If Day 0 is arbitrarily considered as the first day when progesterone concentration is $<1 \mathrm{ng} / \mathrm{ml}$, this maximum was observed at $8.7 \pm 1.0$ days (7-10 days), and the end of the luteolysis at Day $11 \cdot 2 \pm 1 \cdot 0$ (Days 10-12).

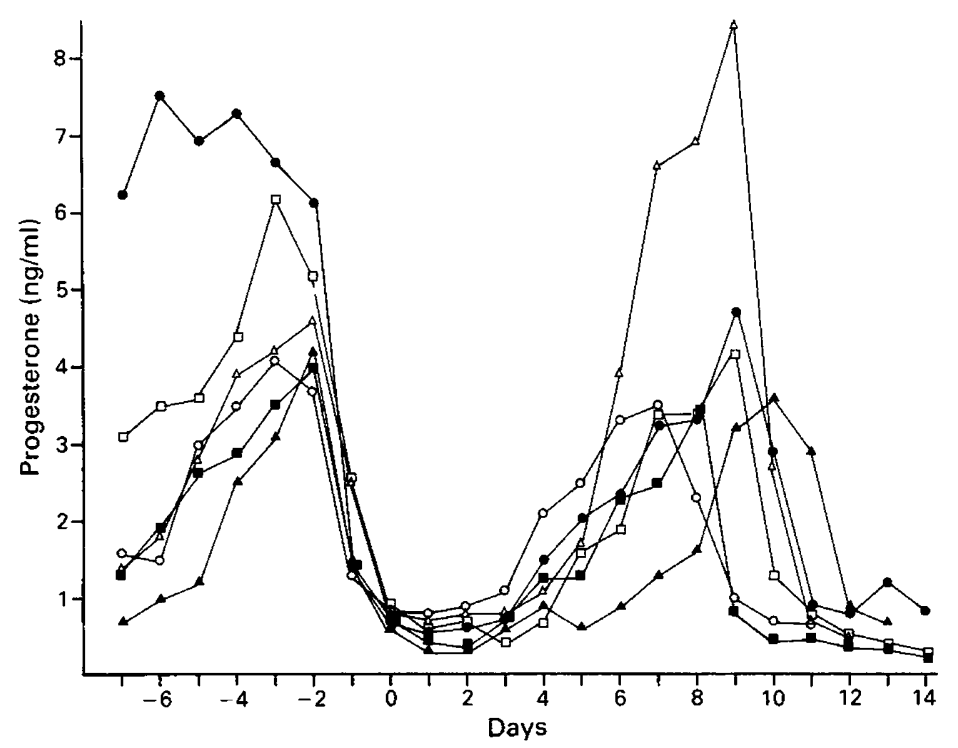

Fig. 3. Plasma progesterone concentrations after decrease of progesterone from a previous corpus luteum $(n=5)$, or after removal of a vaginal coil releasing progesterone $(\bullet, n=1)$ in the one-humped camel. Day 0 is the first day with progesterone level $<1 \mathrm{ng} / \mathrm{ml}$.

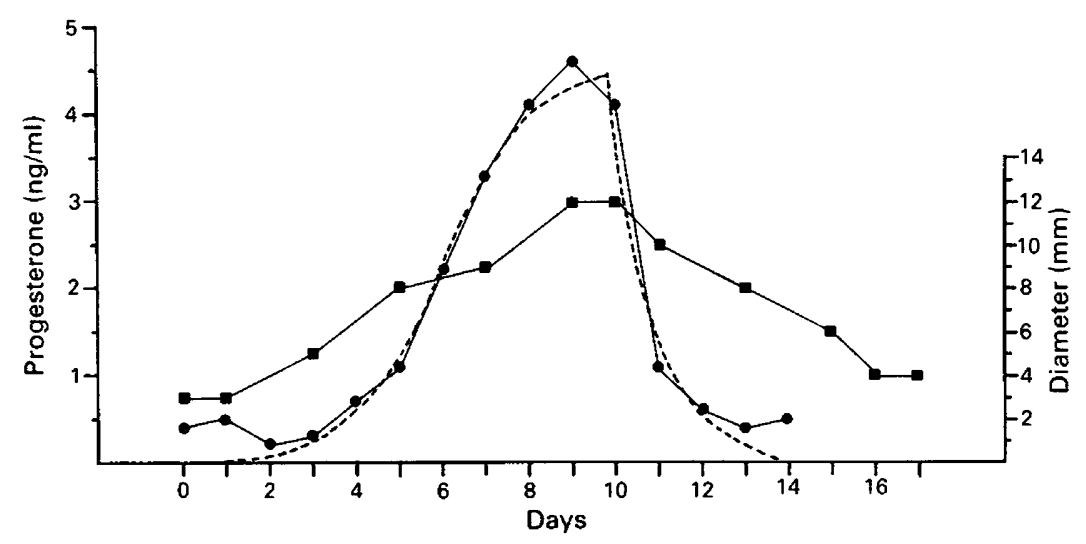

Fig. 4. Observed plasma progesterone concentrations $(\bullet)$, logistic-exponential adjustment $(--)$, and morphological development $(\boldsymbol{D})$ for one corpus luteum in the one-humped camel. Day 0 is day of mating. 
Logistic exponential model of progesterone patterns

The fitness of the progesterone profile to the mathematical model is illustrated for one individual observation in Fig. 4. The goodness of fit is visually demonstrated in the figure and by the coefficients of determination, 0.98 and 0.93 respectively for the first and second part of the pattern. Values of the parameters derived from the estimations made on corpora lutea from each group are reported in Table 1. The coefficients of determination varied from 0.95 to 0.99 for the logistic adjustment, and from 0.92 to 0.99 for the exponential adjustment. No statistical difference was observed for any parameters between the three groups, and therefore a general model for the progesterone pattern has been computed from the whole set of data $(a=5 \cdot 245 \pm 1 \cdot 70$; $\log (b)=4.318 \pm 1 \cdot 149 ; c=0.71 \pm 0.21 ; d=0.786 \pm 0.189 ; T=8.65 \pm 1 \cdot 18)$. The model is illustrated by Fig. 5. The mean concentration at the time of luteolysis $(4.52 \mathrm{ng} / \mathrm{ml})$ is $86 \%$ of the maximum value expected by a logistic law.

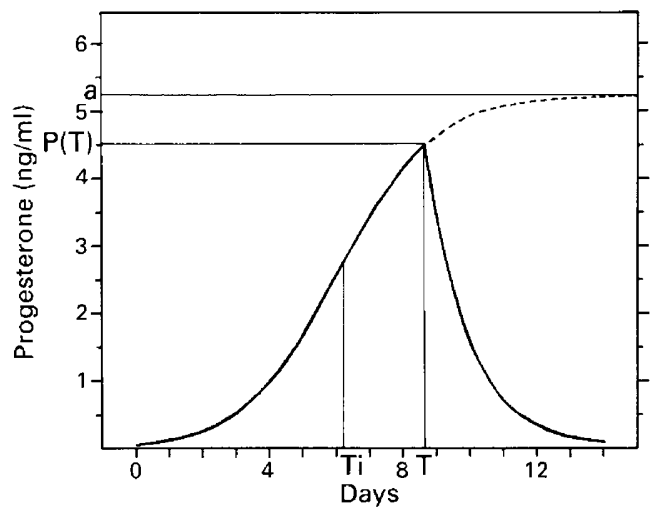

Fig. 5. Theoretical model for plasma progesterone pattern in the one-humped camel after an ovulatory stimulus (Day 0 ). $\mathrm{Ti}=$ time at the inflexion point.

Table 1. Characteristics of progesterone patterns in one-humped camels in Groups A (after mating, $n=11$ ), B (after male introduction, $n=3$ ) and C (after progesterone decrease, $n=6$ )

\begin{tabular}{lccccccc}
\hline & $\begin{array}{c}\text { Progesterone } \\
\text { maximum } \\
(\mathrm{ng} / \mathrm{ml})\end{array}$ & $\begin{array}{c}\text { Day of } \\
\text { maximum } \\
\text { progesterone }\end{array}$ & $\begin{array}{c}\text { Day of } \\
\text { end of } \\
\text { luteolysis }\end{array}$ & $\mathrm{a}$ & $\log (\mathrm{b})$ & $\mathrm{c}$ & $\mathrm{d}$ \\
\hline $\mathrm{A}$ & $4.49 \pm 1.53$ & $8.91 \pm 1.30$ & $12 \cdot 00 \pm 1.00$ & $5.03 \pm 1.93$ & $4.81 \pm 1 \cdot 10$ & $0.80 \pm 0.23$ & $0.84 \pm 0.18$ \\
$\mathrm{~B}$ & $4.20 \pm 0.40$ & $7.00 \pm 1.00$ & $10.66 \pm 0.58$ & $4.93 \pm 0.71$ & $4.14 \pm 0.56$ & $0.68 \pm 0.02$ & $0.66 \pm 0.20$ \\
$\mathrm{C}$ & $4.63 \pm 1.91$ & $8.67 \pm 1.03$ & $11.17 \pm 0.98$ & $5.80 \pm 1.67$ & $3.51 \pm 1.05$ & $0.57 \pm 0.16$ & $0.75 \pm 0.75$ \\
\hline
\end{tabular}

Values are mean \pm s.d.

\section{Morphology of luteal formations}

Out of the 16 luteal formations revealed by progesterone secretion during the period when rectal palpations were performed, $6(37 \%)$ were not detected by palpation, probably because of their small size or their deep position in the ovary. The corpora lutea detected were equally distributed between the two ovaries ( 5 on each side), and did not present any predilective position at the surface of the ovary. They appeared to be round and regular in shape, without discontinuity with 
the rest of the ovary. Their consistency was as firm as the ovary and mature follicles, and firmer than that of the growing follicles. The morphological development of one of the 10 detected formations is illustrated in Fig. 4, showing an increase in synchrony with that of progesterone concentration, and a morphological regression beginning shortly after the progesterone fall, but occurring more slowly. The formations observed became detectable 1-3 days after the ovulatory stimulus. They reached a maximal mean size of $15.5 \pm 5 \cdot 1 \mathrm{~mm}(8-34 \mathrm{~mm})$, at Day $7 \cdot 2 \pm 1.7$ (Day 4-9), while maximum progesterone value for these animals was observed at $8.5 \pm 1.4$ days. They began to regress at $10 \cdot 0 \pm 1 \cdot 2$ days (Day $7-11$ ), but remained detectable until Day $17 \cdot 1 \pm 2 \cdot 6$ (Day 13-21), the largest formations remaining the longest.

\section{Oestrous behaviour and luteal activity}

To explore the mating behaviour of females when a corpus luteum has already been induced by a previous ovulatory stimulus, the male was presented daily to females for 7-11-day periods after a first mating. Complete matings (10) were observed in 5 sequences out of 8 . Seven matings were observed at Days 1-4, when progesterone concentrations were $0.4-1 \mathrm{ng} / \mathrm{ml}$, and 3 at Days $5-7$, associated with elevated progesterone concentration $(2 \cdot 5-3 \cdot 5 \mathrm{ng} / \mathrm{ml})$ (Table 2$)$.

Table 2. Matings observed during the course of development of a corpus luteum in 4 one-humped camels

\begin{tabular}{lcccccccc}
\hline & \multicolumn{8}{c}{ Day } \\
\cline { 2 - 8 } & 1 & 2 & 3 & 4 & 5 & 6 & 7 \\
\hline $\begin{array}{l}\text { No. of matings } \\
\text { observed }\end{array}$ & 1 & - & 3 & 3 & 1 & 1 & 1 \\
$\begin{array}{l}\text { Mean progesterone } \\
\text { conc. (ng/ml) }\end{array}$ & 0.4 & - & 0.8 & 0.8 & 2.5 & 2.9 & 3.5 \\
\hline
\end{tabular}

\section{Discussion}

This paper establishes the short-term evolution of the corpus luteum and the absence of pseudopregnancy in the one-humped camel. Assuming that ovulation occurs $36 \mathrm{~h}$ after the ovulatory stimulus (Williamson \& Payne, 1978), luteolysis begins at 7 days, and is completed 10 days after ovulation. This is in accordance with the observations made for other camelids: in the llama (England et al., 1969), progesterone content of corpora lutea was high at Day 8 but low at Day 16 p.c.; in the alpaca (Fernandez-Baca et al., 1970), progesterone content and weight of corpora lutea were elevated on Day 8 and low on Day 13 after hCG-induced ovulation; in the bactrian camel (Y. H. Gao, Y. S. Xu, H. Y. Wang, G. Q. Zeng \& G. T. Jiang, personal communication), plasma progesterone concentrations were respectively 2.4 and $0.3 \mathrm{ng} / \mathrm{ml}$ at 10 and 15 days after a nonfertile mating or insemination. Elias et al. $(1984,1985)$ reported progesterone values ranging from 3 to $7 \mathrm{ng} / \mathrm{ml}$ in early pregnancy in one-humped camels, and these values are concordant with the maximal levels reported here. However, the increase was quicker, since these authors observed levels above $1 \mathrm{ng} / \mathrm{ml}$ as early as 2 or 3 days after mating, probably due to imprecise identification of the real ovulatory stimulus. The patterns described here are closer to that reported by $\mathrm{Xu}$ et al. (1985) for the bactrian camel during the first 10 days after an ovulatory stimulus. 
By comparison with other farm animals, the progesterone pattern of the one-humped camel is characterized by the absence of a plateau, and early luteolysis. Luteolytic factors are unknown in the one-humped camel. Prostaglandin-F2 $\alpha$ is probably involved, since Fernandez-Baca et al. (1979) have demonstrated a luteolytic effect of uterine horns in the alpaca. It can therefore be inferred that prostaglandin release by the uterus, or the action of another luteolytic mechanism, occurs early after coitus (7-8 days), as well as the embryonic signal of pregnancy recognition.

Morphological development of the corpus luteum, lasting here 2-3 weeks, is very similar to that reported for the bactrian camel by Chen \& Yuen (1984), but is longer than that found for the one-humped camel by Musa \& Abusineina (1978). Although the start of morphological regression is closely related to the plasma progesterone decrease, this process is long, and the presence of a palpable body is not indicative of its functional activity.

The time-course of progesterone secretion described here offers the opportunity to set up a very early pregnancy diagnosis based on plasma progesterone concentrations, with a period of application corresponding to 12-13 days after mating. We observed that females will accept the male again 12-13 days after a sterile mating; Chen \& Yuen (1984) also reported matings from 13 days after a sterile service in the bactrian camel, and England et al. (1969) observed matings and ovulations 12 days after a previous ovulation in the alpaca. This information is of practical importance to raise the chances of fecundation when the male is not continuously present with the females, as breeders usually wait 40 days (date of the appearance of the first external signs of pregnancy) before permitting a new mating, and as sexual activity is limited in the year for the male and the female.

In animals of most species, mating behaviour is strictly limited to the period of oestrus, but progesterone does not completely inhibit male acceptance in the one-humped camel. This has also been reported for the bactrian camel (Chen \& Yuen, 1984), with new matings observed 2-8 days after a first copulation, concurrently with the morphological development of a corpus luteum. This could be explained by the existence of growing follicles: Shalash \& Nawito (1964) and Abdo et al. (1969) observed follicular structures in the ovary during the luteal phase, and Musa (1979) reported follicular growth and matings during pregnancy. Acceptance of the male cannot therefore be interpreted as being strictly associated with an absence of progesterone secretion.

The induction of ovulation by mating in one-humped camels is confirmed by the fact that $73 \%$ of the matings were followed by luteal formation. Two of the unsuccessful services observed are explained by an absence of hypophysial response, as revealed by the lack of LH release in these animals (Marie \& Anouassi, 1986). Considering only females in sexual activity, the incidence of ovulation after mating was in fact $85 \%$. However, rectal palpations alone, as well as vaginal and cervical stimulations, which were performed daily for $15-20 \mathrm{~min}$, did not elicit ovulation. This observation, similar to those reported by Musa \& Abusineina (1978) and Elias et al. (1984), shows that the neural stimulus is not similar to that reported for the rabbit or the cat. Chen et al. (1985) presented evidence for semen-induced ovulation in the bactrian camel, with some augmentative effect of the mating behaviour. Nevertheless, mating is not a necessary prerequisite for ovulation in the one-humped camel. Ovulations without mating were also observed when a male was introduced after a prolonged period of separation from the females. The male effect has been shown, in the anoestrous ewe, to increase the tonic pulsatile secretion of $\mathrm{LH}$ and to induce a preovulatory $\mathrm{LH}$ surge (Signoret et al., 1983). Secondly, endocrinological factors can also interfere, and progesterone withdrawal seems to liberate hypothalamo-hypophysial centres from a negative influence with consequent gonadotrophin release. The low incidence of these observations $(23 \%)$ may be related to the simultaneous intervention of other components, such as elevated concentrations of oestrogens. Hormonally induced ovulation has been reported for other induced ovulators (cat: Foster \& Hisaw, 1935; rabbit: Sawyer et al., 1950), after combined oestrogen-progesterone treatment.

Therefore, the one-humped camel can be considered as an induced ovulator in which the mechanisms operating in spontaneous ovulators can be effective in certain situations. 
We thank the National Zoological Park of Temara for the care of the animals; Professor A. Lahlou-Kassi for laboratory facilities; Professor J. F. Beckers for providing the antibody to progesterone; Mr Y. Berger for editorial assistance; and Dr E. Palmer and Dr J. C. Mariana for reading the manuscript.

\section{References}

Abdalla, O. (1965) Anatomical study of the female genital system of the one-humped camel (Camelus dromedarius). I. The ovaries. Sud. J. vet. Sci. anim. Husb. 6, 41-52.

Abdo, M.S., Al Janabi, A.S. \& Al Kafawi, A.A. (1969) Studies on the ovaries of the female camel during the reproductive cycle and in conditions affected with cysts. Cornell Vet. 59, 418-425.

Assouel, A. (1983) Contribution à l'endocrinologie de la gestation dans l'espèce Camelus dromedarius. Thèse doct. vet., Rabat.

Bachacou, J.F., Masson, J.P. \& Millier, C. (1981) Manuel de la programmathèque Amance 81. Département de Biométrie, INRA, Jouy-en-Josas.

Beckers, J.F., Ballman, P., Ectors, F. \& Derivaux, J. (1975) Dosage radioimmunologique de la progestérone plasmatique chez la vache. $C$. $r$. hebd. Séanc. Acad. Sci. Paris D 280, 335-338.

Chen, B.X. \& Yuen, Z.X. (1984) Reproductive pattern of the bactrian camel. In The Camel, pp. 364-386. Ed. W. R. Cockrill. Scandinavian Institute of African Studies, Uppsala.

Chen, B.X., Yuen, Z.X. \& Pan, G.W. (1985) Semeninduced ovulation in the bactrian camel (Camelus bactrianus). J. Reprod. Fert. 74, 335-339.

Elias, E., Bedrak, E. \& Yagil, R. (1984) Peripheral blood levels of progesterone in female camels during various reproductive stages. Gen. comp. Endocr. 53, $235-240$.

Elias, E., Bedrak, E. \& Cohen, D. (1985) Induction of oestrus in the camel (Camelus dromedarius) during seasonal anoestrus. J. Reprod. Fert. 74, 519-525.

England, B.G., Foote, W.C., Matthews, D.H., Gardozo, A.G. \& Riera, S. (1969) Ovulation and corpus luteum function in the llama, Lama glama. J. Endocr. 45, $505-513$.

Fernandez-Baca, S., Hansel, W. \& Novoa, C. (1970) Corpus luteum function in the alpaca. Biol. Reprod. 3, 252-261.

Fernandez-Baca, S., Hansel, W., Saatman, R., Sumar, J. \& Novoa, C. (1979) Differential luteolytic effects of right and left uterine horns in the alpaca. Biol. Reprod. 20, 586-595.

Foster, M.A. \& Hisaw, F.L. (1935) Experimental ovulation and the resulting pseudopregnancy in anoestrus cats. Anat. Rec. 62, 75-93.

Heap, R.B. \& Hammond, J. (1974) Plasma progesterone in pregnant and pseudopregnant ferrets. J. Reprod. Fert. 39, 149-152.

Lebart, L., Morineau, A. \& Fénelon, J.P. (1980) Traitement des Données Statistiques. Méthodes et Programmes. Dunod, Paris.

Marie, M. \& Anouassi, A. (1986) Mating induced LH surge and ovulation in the female camel (Camelus dromedarius). Biol. Reprod. 35, 792-798.
Marie, M., Dewulf, M., Thibier, M. \& Lahlou-Kassi, A. (1984) Mise en place au Maroc d'un diagnostic précoce de gestation par dosage de la progestérone dans le lait de vache. Maghreb Vétérinaire 1 (4), 9-14.

Marquardt, D.W. (1963) An algorithm for least-squares estimation of non linear parameters. J. Soc. Indust. Appl. Math. 11, 431-441.

Miller, J.B. \& Keyes, P.L. (1976) A mechanism for regression of the rabbit corpus luteum: uterineinduced loss of luteal responsiveness to I7 $\beta$-estradiol. Biol. Reprod. 15, 511-518.

Moller, O.M. (1973) Progesterone concentration in the peripheral plasma of the mink (Mustela vison). $J$. Endocr. 56, 121-132.

Musa, B.E. (1979) Studies on the ovary of the camel (Camelus dromedarius), Sudan J. vet. Sci. Anim. Husb. 20, 51-64.

Musa, B.E. \& Abusineina, M.E. (1978) The oestrous cycle of the camel (Camelus dromedarius). Vet. Rec. 103, $556-557$.

Nawar, S.M., Abul-Fadle, W.S. \& Mahmoud, S.A. (1978) Studies on the ovarian activity of the dromedary (Camelus dromedarius). Z. mikrosk. anat. Forsch. 92, $385-408$

Nawito, M.F., Shalash, M.R., Hopper, R. \& Rakha, A.M. (1968) Reproduction in female camel. Vet. Bull. 38, Abstr. 809.

Sawyer, C., Everett, J. \& Markee, J.E. (1950) 'Spontaneous' ovulation in the rabbit following combined estrogen-progesterone treatment. Proc. Soc. exp. Biol. Med. 74, 185-186.

Shalash, M.R. \& Nawito, M. (1964) Some reproductive aspects in the female camel. Proc. 5th Int. Cong. Anim. Reprod. \& A.I., Trento 2, 263-273.

Signoret, J.P., Cognie, Y. \& Martin, G.B. (1983) The effect of males on female reproductive physiology. In The Male in Farm Animal Reproduction, pp. 290-304. Ed. M. Courot. Martinus Nijhoff, Amsterdam.

Sumar, J. \& Garcia, M. (1986) Fisiologia reproductiva en los camelidos sudamericanos: alpaca y lama. In Proc. IAEA-SM-292 Int. Symp., Vienna, pp. $26-27$.

Tayeb, M.A.F. (1950) Etude sur l'anatomie de l'ovaire et du corps jaune de la chamelle. Rev. Élev. Méd. vét. Pays trop. 4, 177-182.

Verhage, H.G., Beamer, N.B. \& Brenner, R.M. (1979) Plasma levels of estradiol and progesterone in the cat during polyestrus, pregnancy and pseudopregnancy. Biol. Reprod. 14, 579-585.

Wildt, D.E., Platz, C.C., Chakraborty, P.K. \& Seager, S.W.J. (1979) Oestrous and ovarian activity in a female jaguar (Panthera onca). J. Reprod. Fert. 56, $555-558$.

Wildt, D.E., Chan, S.Y.M., Seager, S.W.J. \& Chakraborty, P.K. (1981) Ovarian activity, circulating hormones and sexual behavior in the cat. I. 
Relationships during the coitus-induced luteal phase and the estrous period without mating. Biol. Reprod. $25,15-28$.

Williamson, G. \& Payne, W.J.A. (1978) An Introduction to Animal Husbandry in the Tropics. Longmans, London.

Xu, Y.S., Wang, H.Y., Zeng, G.Q., Jiang, G.T. \& Gao, Y.H. (1985) Hormone concentrations before and after semen-induced ovulation in the bactrian camel (Camelus bactrianus). J. Reprod. Fert. 74, 341-346.
Yenikoe, A., Mariana, J.C., Ley, J.P., Jolivet, E., Terqui, M. \& Lemon-Resplandy, M. (1981) Modèle mathématique de l'évolution de progestérone chez la vache: application et mise en évidence de différence entre races. Reprod. Nutr. Dévelop. 21, 561-575.

Received 19 August 1986 